\title{
SCIENTIFIC REPRTS \\ OPEN Corrigendum: Maintained larval growth in mussel larvae exposed to acidified under-saturated seawater
}

\section{Alexander Ventura, Sabrina Schulz \& Sam Dupont \\ Correction to: Scientific Reports https://doi.org/10.1038/srep23728; published online 29 March 2016; updated 27} June 2018

This Article contains errors.

In Table 1, in the sixth row, the $\mathrm{pH}_{\mathrm{T}}$ value for nominal $\mathrm{pH} 7.85$,

“7.80 $\pm 0.031 ”$

should read:

“7.86 $\pm 0.031 ”$

Additionally, the legend for Figure 2,

“(a) Trochophore stage, (b) protruding mantle, (c) indented margin, $(\mathbf{d})$ convex hinge, (e) cupped and (f) normally D-shaped larva. N. B. All photos are from experiment day 11.”

should read:

“(a) Trochophore stage, (b) protruding mantle, (c) indented margin, (d) convex hinge, (e) cupped and (f) normally D-shaped larva. N. B. The larva in panel (a) is from experiment day 4 whilst larvae in remaining panels are from day 11 ".

(c) (i) This work is licensed under a Creative Commons Attribution 4.0 International License. The images or other third party material in this article are included in the article's Creative Commons license, unless indicated otherwise in the credit line; if the material is not included under the Creative Commons license, users will need to obtain permission from the license holder to reproduce the material. To view a copy of this license, visit http://creativecommons.org/licenses/by/4.0/

(c) The Author(s) 2018 